\title{
Tiên phong nối vào CSDL Web of Science, Nature tiếp sức ISI nổ súng tấn công Scopus
}

Hồ Mạnh Toàn

A.I. for Social Data Lab

Hà Nội, 12-3-2019

Cách đây chưa lâu, chúng tôi quan sát được việc ISI Web of Science quyết giành lãnh thổ dữ liệu số từ tay Scopus và ho "powering" hệ thống Publons với dữ liệu trích dẫn miễn phí cho các nhà nghiên cứu có tài khoản Publons [1].

Đó là một bước tiến ghê gớm, rất nhiều ích lợi cho xã hội.

Tuy nhiên, có những hạn chế đáng kể với mức độ "publicity" vì người dùng (nếu không phải chính là tác giả với Publons cá nhân) do cần thỏa mãn các điều kiện sau để thông tin có thể trở nên hữu ích:

a) Phải biết đích xác tác giả;

b) biết đích xác địa chỉ Publons;

c) phải biết đích xác bài, và bài đó đã được tác giả "import" về CSDL qua ORCID hoặc chính Web of Science của Clarivate Analytics.

Dường như để tiếp tục tăng cường hỏa lực "open data" cho trận chiến với Scopus, Web of Science đã mở rộng powering một số hệ thống thương hiệu hàng đầu. Cụ thể nhất, hôm nay chúng tôi nhận thấy các tạp chí của Nature Research truy cập qua nature.com đã cung cấp dữ liệu trích dẫn đo từ Web of Science bên cạnh dữ liệu mở sẵn có của CrossRef.

Một ví dụ cụ thể là nghiên cứu tại địa chỉ: https://www.nature.com/articles/s41599-018-0189-2 [2], trong hình dưới đây. 
Article OPEN Published: 04 December 2018

Cultural additivity: behavioural insights from the interaction of Confucianism, Buddhism and Taoism in folktales

Quan-Hoang Vuong, Quang-Khiem Bui, Viet-Phuong La, Thu-Trang Vuong, Viet-Ha T. Nguyen, ManhToan Ho, Hong-Kong T. Nguyen \& Manh-Tung Ho

Polgrove Communicotions 4, Article number: 143 (2018) Download Citation \pm

\section{Abstract}

Computational folkloristics, which is rooted in the movement to make folklore studies more scientific, has transformed the way researchers in humanities detect patterns of cultural transmission in large folklore collections. This interdisciplinary study contributes to the literature through its application of Bayesian statistics in analyzing Vietnamese folklore. By breaking down 307 stories in popular Vietnamese folktales and major story collections and categorizing their core messages under

\begin{tabular}{|c|c|c|}
\hline D & W & 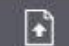 \\
\hline Search & E-alert & Submit \\
\hline
\end{tabular}

Download PDF$$
\begin{array}{l|l|l}
\mathbf{4} & \mathbf{3 7} & \\
\text { Citations } & \text { Altmetric } & \text { Article metrics 》 }
\end{array}
$$

\begin{tabular}{l|l|l|}
\hline \multicolumn{1}{|c|}{ Sections } & Figures & References \\
\cline { 2 - 2 } Abstract \\
Introduction \\
\hline Literature review \\
Methods \\
Results \\
Discussion \\
Conclusion \\
Additional information \\
Notes \\
References \\
Acknowledgements
\end{tabular}

Acknowledgements

\section{[Hình 1]}

Ở góc cao tay phải, có thể thấy phần Citation và Altmetric. Click vào đường dẫn "Article metrics" sẽ mở ra trang: https://www.nature.com/articles/s41599-0180189-2/metrics (xem Hình 2 bên dưới). 
Article metrics for:

Cultural additivity: behavioural insights from the interaction of Confucianism, Buddhism and Taoism in folktales

Total citations

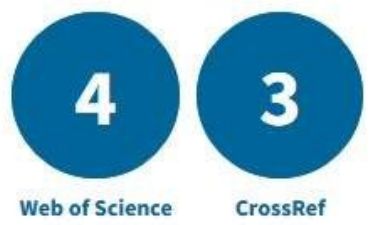

Mentions in news, blogs \& Google+
Online attention

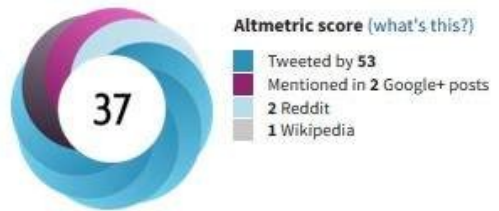

This Altmetric score means that the article is:

- in the $93^{\text {rd }}$ percentile (ranked $17,969^{\text {th }}$ ) of the 283,735 tracked articles of a similar age in all journals

- in the $84^{\text {th }}$ percentile (ranked $10^{\text {th }}$ ) of the 63 tracked articles of a similar age in

Polgrave Communications

Twitter demographics

[Hình 2]

Bây giờ, click vào ô tròn có số thống kê trích dẫn tương ứng với Web of Science (Clarivate Analytics ISI), độc giả sẽ được dẫn đến trang dữ liệu do Web of Science cung cấp (Hình 3). 


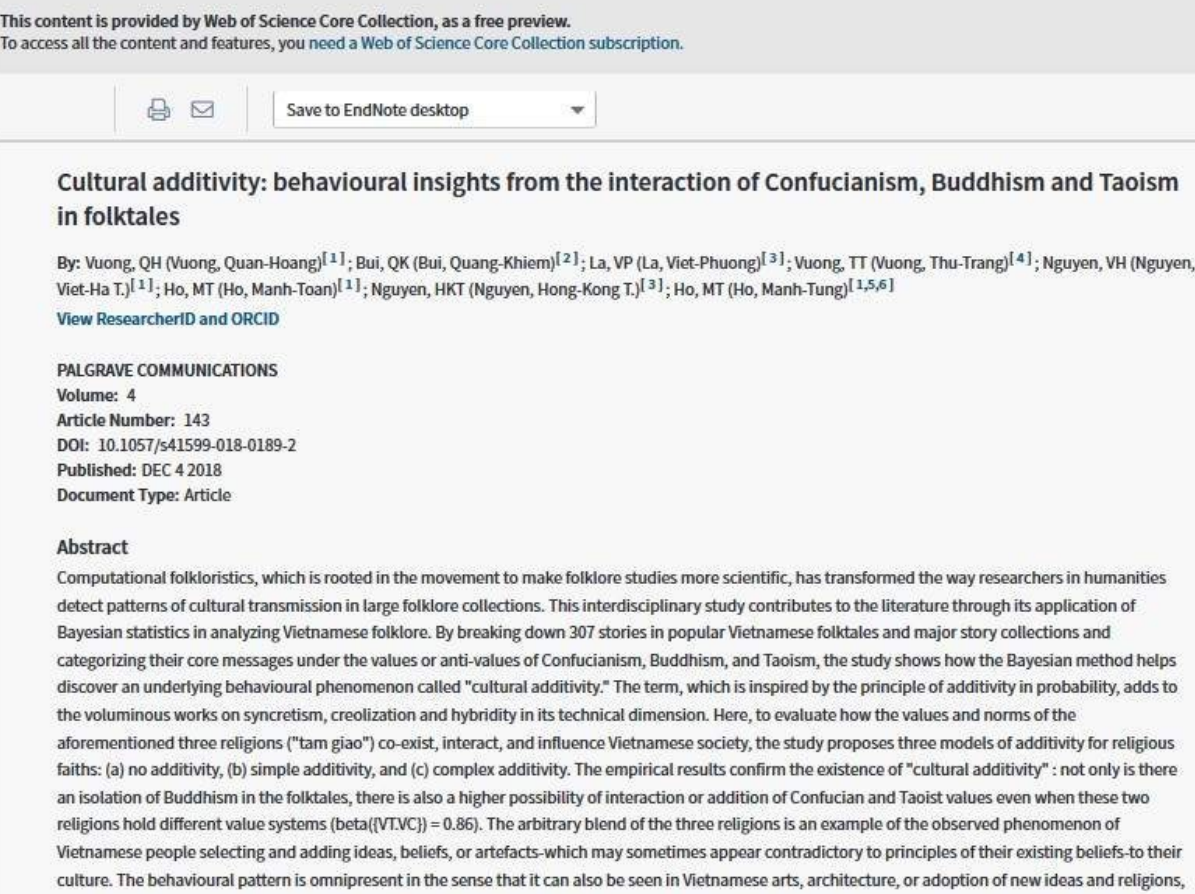

Cultural additivity: behavioural insights from the interaction of Confucianism, Buddhism and Taoism in folktales

By: Vuong, QH (Vuong, Quan-Hoang) ${ }^{[1]}$; Bui, QK (Bui, Quang-Khiem) $)^{[2]}$; La, VP (La, Viet-Phuong) $)^{[3]}$; Vuong, $T$ (Nuong, Thu-Trang) ${ }^{[4]}$; Nguyen, VH (Nguyen, Viet-Ha T. $)^{[1]} ;$ Ho, MT (Ho, Manh-Toan) ${ }^{[1]} ;$ Nguyen, HKT (Nguyen, Hong-Kong T.) ${ }^{[3]} ;$ Ho, MT (Ho, Manh-Tung) ${ }^{[1,5,6]}$

View ResearcherID and ORCID

PALGRAVE COMMUNICATIONS

Volume: 4

Article Number: 143

DOI: $10.1057 / 541599-018-0189-2$

Published: DEC 42018

Document Type: Article

Abstract

Computational folkloristics, which is rooted in the movement to make folklore studies more scientific, has transformed the way researchers in humanities detect patterns of cultural transmission in large folklore collections. This interdisciplinary study contributes to the literature through its application of Bayesian statistics in analyzing Vietnamese folklore. By breaking down 307 stories in popular Vietnamese folktales and major story collections and categorizing their core messages under the values or anti-values of Confucianism, Buddhism, and Taoism, the study shows how the Bayesian method helps discover an underlying behavioural phenomenon called "cultural additivity." The term, which is inspired by the principle of additivity in probability, adds to the voluminous works on syncretism, creolization and hybridity in its technical dimension. Here, to evaluate how the values and norms of the aforementioned three religions ("tam giao") co-exist, interact, and influence Vietnamese society, the study proposes three models of additivity for religious faiths: (a) no additivity, (b) simple additivity, and (c) complex additivity. The empirical results confirm the existence of "cultural additivity" : not only is there an isolation of Buddhism in the folktales, there is also a higher possibility of interaction or addition of Confucian and Taoist values even when these two religions hold different value systems (beta(IVTVC) $=0.86$ ). The arbitrary blend of the three religions is an example of the observed phenomenon of Vietnamese people selecting and adding ideas, beliefs, or artefacts-which may sometimes appear contradictory to principles of their existing beliefs-to their culture. The behavioural pattern is omnipresent in the sense that it can also be seen in Vietnamese arts, architecture, or adoption of new ideas and religions,

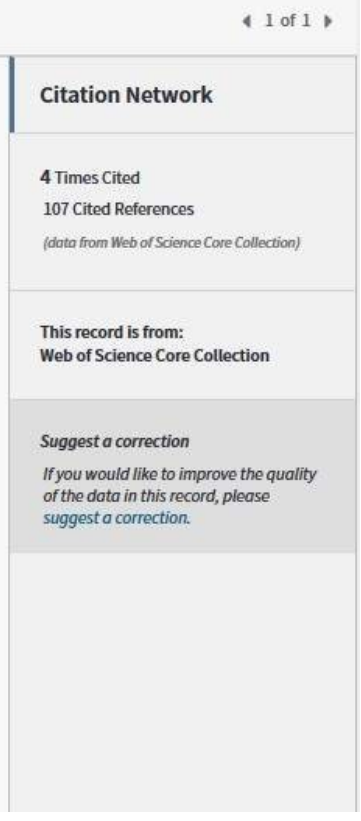

\section{[Hình 3]}

Tương tự với các bài khác trên hệ thống của Nature, ví dụ bài: https://www.nature.com/articles/s41562-017-0281-4 [3] sẽ dẫn đến CSDL của Web of Science như Hình 4 dưới đây.

\section{Web of Science}

This content is provided by Web of Science Core Collection, as a free preview.

To access all the content and features, you need a Web of Science Core Collection subscription.

믐 $\triangle$ Save to EndNote desktop

The (ir) rational consideration of the cost of science in transition economies

By: Vuong, QH (Vuong, Quan-Hoang) ${ }^{[1]}$

View ResearcherID and ORCID

NATURE HUMAN BEHAVIOUR

Volume: 2 Issue: 1 Pages: $5-5$

DOI: $10.1038 / 541562-017-0281-4$

Published: JAN 2018

Document Type: Editorial Materia

Author Information

Reprint Address: Vuong, QH (reprint author)

Western Univ Hanoi, Ctr Interdisciplinary Social Res, Hanoi, Vietnam. Addresses:

[1] Western Univ Hanoi, Ctr Interdisciplinary Social Res, Hanoi, Vietnam

E-mail Addresses: hoang.vuong@wu.edu.vn

Publisher

NATURE PUBLISHING GROUP, 75 VARICK ST, 9TH FLR, NEW YORK, NY 10013-1917 USA

Categories / Classification

Research Areas: Psychology; Science \& Technology - Other Topics; Neurosciences \& Neurology

Web of Science Categories: Psychology, Biological; Multidisciplinary Sciences; Neurosciences; Psychology, Experimental

Citation Network

11 Times Cited

0 Cited References

(doto from Web of Science Core Collection

This record is from: Web of Science Core Collection

Suggest a correction If you would like to improve the quality of the data in this record, please suggest a correction. 
[Hình 4]

Điều đáng chú ý là số liệu trích dẫn trên WOS được powered rất mạnh, nên tốc độ cập nhật tốt, nên có thực tế hơi lạ là còn cao hơn cả trích dẫn của CrossRef cung cấp. Như hình 5 , số trích dẫn WOS là 11, trong khi từ CrossRef mới có 10.

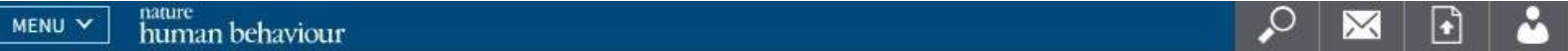 \\ Article metrics for: \\ The (ir)rational consideration of the cost of science in transition economies}

Last updated: Tue, 12 Mar 2019 05:28:23 GMT

Back to article page 》

Total citations

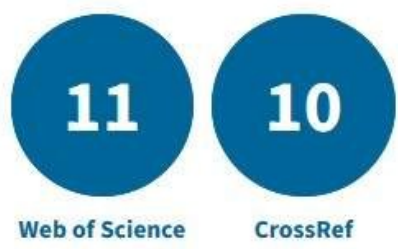

Mentions in news, blogs \& Google+
Online attention

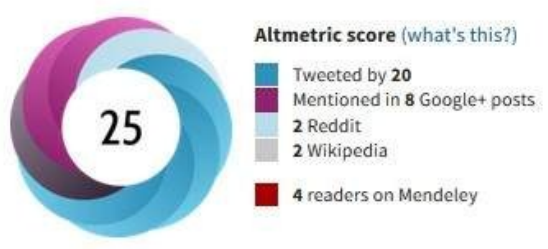

This Altmetric score means that the article is:
- in the $92^{\text {nd }}$ percentile (ranked $26,448^{\text {th }}$ ) of the 349,632 tracked articles of a
similar age in all journals
- in the $47^{\text {th }}$ percentile (ranked $33^{\text {rd }}$ ) of the 63 tracked articles of a similar age in
Nature Human Behaviour

Twitter demographics

[Hình 5]

Điều này thoạt trông sẽ rất không bình thường vì hầu hết các ấn phẩm ngày nay đều có DOI và hầu hết đều được quản lý bởi CrossRef, trong khi các tạp chí thuộc ISI Web of Science chỉ chiếm một tỷ lệ nhỏ trong đó. Nên thường thì số liệu trích dẫn từ WOS sẽ nhỏ hơn của CrossRef rất nhiều. Tuy nhiên, với quyết tâm cho thấy sức mạnh của hệ thống dữ liệu ISI WOS, thì việc cập nhật còn tốt hơn cả CrossRef đã dẫn đến tình hình như đã thấy.

Một quan sát nữa giúp nhận biết cuộc chiến leo thang. Cách chừng một năm rưỡi, hệ thống Nature có 3 ô tròn dữ liệu trích dẫn từ WOS, CrossRef và Scopus. Trong một thời gian dài, dữ liệu Scopus cung cấp rất "mượt", và cũng tương tự như WOS hiện nay, còn nhanh và đủ hơn cả CrossRef. Chính thời điểm đó, dữ liệu WOS lại không hề được cập nhật. Nhưng kể từ khi cuộc chiến leo thang, ô tròn dữ liệu Scopus đã bị "biến mất"; và bây giờ có vẻ vị thế đảo ngược vào tay WOS.

Một lần nữa chúng ta lại ngóng xem tiếp theo các "đại gia" dữ liệu khoa học sẽ làm gì với thế giới ấn phẩm khoa học mà họ đang làm mưa làm gió. 
Notes: Published in SSHPA: https://sc.sshpa.com/post/4421.

\section{References:}

[1] SciComm SSHPA. (2018, December 9). ISI Web of Science đưa vũ khí "open data" vào trận chiến giành lại lãnh thổ bị mất từ tay Scopus. SciComm SSHPA. Retrieved from https://sc.sshpa.com/post/4354 (March 12, 2019).

[2] Vuong, Q. H., Bui, Q. K., La, V. P., Vuong, T. T., Nguyen, V. H. T., Ho, M. T., ... \& Ho, M. T. (2018). Cultural additivity: Behavioural insights from the interaction of Confucianism, Buddhism, and Taoism in folktales. Palgrave Communications, 4, 143, DOI: $10.1057 / \mathrm{s} 41599-018-0189-2$.

[3] Vuong, Q. H. (2018). The (ir)rational consideration of the cost of science in transition economies. Nature Human Behaviour, 2, 5, DOI: 10.1038/s41562017-0281-4. 